\title{
Responses of Growth and Ion Uptake of Four Rose Rootstocks to Chloride- or Sulfate-dominated Salinity
}

\author{
Genhua Niu ${ }^{1}$ and Denise S. Rodriguez \\ Department of Horticultural Sciences, Texas AgriLife Research Center at El Paso, Texas A\&M \\ System, El Paso, TX 79927
}

\begin{abstract}
Additional INDEX words. Rosa, saline water irrigation
Abstract. Salt-tolerant garden roses (Rosa L.) are needed for arid and semiarid regions where high-quality water supply is limited and soil salinization often occurs. This greenhouse study evaluated growth, ion uptake characteristics, and the daily evapotranspiration rate (ET) of four rose rootstocks ['Dr. Huey' (Rosa $\times$ hybrida L.), R. $\times$ fortuniana Lindl., $R$. multiflora Thunb., and $R$. odorata (Andr.) Sweet] irrigated with saline solutions with chloride or sulfate as the dominant salts. After 16 weeks of treatment, the elevated salinities reduced growth of all rootstocks, but the magnitude varied with the rootstock and dominant salt type. At moderate $\left[3.9 \mathrm{dS} \cdot \mathrm{m}^{-1}\right.$ electrical conductivity (EC)] and high salinities $\left(7.9\right.$ to $\left.8.2 \mathrm{dS} \cdot \mathrm{m}^{-1}\right)$, chloride-dominated salinity led to a greater growth reduction in $R$. $\times$ fortuniana, followed by $R$. odorata and $R$. multiflora. At high salinity dominated by sulfate, $R$. odorata had a greater growth reduction, followed by $R$. multiflora, 'Dr. Huey', and $R$. $\times$ fortuniana. For $R$. multiflora, growth was reduced more in chloride-dominated salinity at high salinity levels, but no differences were found in the growth between the two salt types at moderate salinity. Rosa multiflora accumulated more Na than $R$. odorata, and $R$. $\times$ fortuniana accumulated the least. However, $R$. multiflora retained most the $\mathrm{Na}$ in the roots, whereas $R$. odorata transported $57 \%$ of the Na to shoots. All rootstocks had a similar high leaf $\mathrm{Cl}$ concentration at high salinity dominated by chloride, while $R$. $\times$ fortuniana had the most severe foliar salt damage, indicating that $R$. $\times$ fortuniana had a lower threshold concentration of tissue Cl. At moderate salinity, all rootstocks had acceptable visual quality. At high salinity, the appearance of all rootstocks declined with typical salt damage on lower, older leaves, and the plants had lower visual scores in chloridedominated salinity, especially in $R$. $\times$ fortuniana. Salinity treatment did not affect the daily ET per unit leaf area, regardless of rootstock and dominant salt type. Daily ET per pot was the smallest in $R$. $\times$ fortuniana among the four rootstocks due to its smaller total leaf area. The four rootstocks responded differently to salinity and dominant salt type.
\end{abstract}

Alternative water sources, such as reclaimed water, are being used to irrigate urban landscapes and agricultural crops due to the limited supply of fresh water, especially in arid and semiarid regions of the world. Reclaimed water contains relatively high levels of soluble salts compared with fresh water, and its salinity level depends on the source of water and treatment. For example, in California, the electrical conductivity (EC) of reclaimed water is typically two to three times that of fresh water (Wu et al., 2001). In addition to elevated salinity of irrigation water, soil salinization has occurred in more than 100 countries (Rengasamy, 2006). The soil salinity problem is even worse in arid and semiarid regions due to high evaporation rates, low rainfall, and irrigation with alternative water sources. Therefore, salt-tolerant plants are required in arid and semiarid regions to maintain aesthetically appealing landscapes.

The rose is one of the most economically important and widely grown ornamental crops worldwide. Information available on the salt tolerance of roses as cut flowers (Bernstein et al., 2006; Cabrera, 2001, 2002, 2003; de Vries, 2003; FernándezFalcón et al., 1986; Hughes and Hanan, 1978; Raviv et al., 1998; Wahome et al., 2001) indicates that like other crops, salinity tolerance of rose plants depends on species, rootstock

Received for publication 12 May 2008. Accepted for publication 13 June 2008. This work was supported by the Cooperative State Research, Education and Extension Service, U.S. Department of Agriculture under Agreement No. 200534461-15661, and by El Paso Water Utilities. We also thank Jackson and Perkins Wholesale, Inc., for donating the plant materials.

${ }^{1}$ Corresponding author. E-mail: gniu@ag.tamu.edu. selection, substrate or soil type, and environmental conditions. However, little research has been conducted on garden roses under elevated salinity conditions.

Most garden roses are produced by grafting using the Tbudding technique (Pemberton, 2003). Different rootstocks are recommended in various areas in the world based on regional differences in climate and soil conditions, in addition to the consideration of rootstock and scion compatibility. For example, R. multiflora is used in the south-central United States, Canada, and Japan, whereas 'Dr. Huey' is used in the western United States (Pemberton, 2003). $R$. xfortuniana is used in areas with year-round temperate climate (Morrell, 1983). In the United States, $R$. $\times$ fortuniana is mainly used in Florida and in the southwestern region (Martin, 2008). R. odorata is one of the most popular rose rootstocks for greenhouse cut flowers, but the species is also valued for garden roses (Cabrera, 2002; Singh and Chitkara, 1982, 1987).

Limited research compares the salt tolerance of various rose rootstocks. Wahome et al. (2001) compared the salt tolerance of two rose rootstocks and found that $R$. rubiginosa $\mathrm{L}$. was more tolerant to $\mathrm{NaCl}$ stress than was $R$. chinensis Jacq. 'Major'. Cabrera (2003) investigated the salt tolerance of 'Bridal White' grafted onto five rose rootstocks and found that its salt tolerance was higher when grafted onto Rosa 'Manetti' and 'Natal Briar' than $R$. odorata (syn. $R$. indica L. 'Major'), R. multiflora 'Rum 9', and 'Dr. Huey'. However, the relative salt tolerance of the five rootstocks alone (without grafting with scions) remains unknown. Comparison of the response of rose rootstocks alone 
to salinity will be helpful in understanding the mechanism of salt tolerance of major commercial rose rootstocks.

Most saline water and saline soils are dominated by chloride or sulfate salts (Manchanda and Sharma, 1989; Rogers et al., 1998). However, much of the research quantifying the salt tolerance of plant species has been based on experiments in which $\mathrm{NaCl}$ is the predominant salt. The degree of salt tolerance depends on the dominant salt type and species (Khan et al., 1995; Rogers et al., 1998). For example, sulfate salts were less deleterious than chloride salts to sweet pepper (Capsicum annuum L.) (Navarro et al., 2002), chickpea (Cicer arietinum L.) (Manchanda and Sharma, 1989), and siberian larch (Larix siberica L.) (Carter, 1980). Specific ions can affect mineral metabolism by promoting or inhibiting the uptake of other minerals (Carter, 1980). Salt type may also affect physiological parameters such as photosynthetic rates and transpiration rates (Meiri et al., 1971). Therefore, the objectives of this study were to compare the growth, ion uptake, and the daily evapotranspiration rate (ET) of four major rose rootstocks 'Dr. Huey', $R$. ×fortuniana, $R$. multiflora, and $R$. odorata in response to various salinity levels of irrigation solutions and to investigate if the dominant salt type affects the degree of salt tolerance of these rootstocks.

\section{Materials and Methods}

Plant materials and Culture. Rooted cuttings of 'Dr. Huey', $R$. ×fortuniana, $R$. multiflora, and $R$. odorata were received from a commercial company (Jackson and Perkins Co., Medford, OR) on 10 Oct. 2006. Cuttings were transplanted immediately to 2.6-L plastic pots containing a 1:1 mix (by volume) of Sunshine Mix No. 4 (SunGro Horticulture, Bellevue, WA) and composted mulch (Western Organics, Tempe, AZ) amended with $5 \mathrm{~kg} \cdot \mathrm{m}^{-3}$ dolomite limestone (Carl Pool EarthSafe Organics, Gladewater, TX) and $1 \mathrm{~kg} \cdot \mathrm{m}^{-3}$ Micromax (Scotts, Marysville, OH). Plants were transplanted again on 28 Feb. 2007 to $10-\mathrm{L}$ containers containing the same growing substrate as in the 2.6-L containers. Plants were grown in the greenhouse before the initiation of treatments and were irrigated with a nutrient solution containing $0.5 \mathrm{~g} \cdot \mathrm{L}^{-1}$ of $20 \mathrm{~N}-8.6 \mathrm{P}-16.7 \mathrm{~K}$ (Peters 20 20-20; Scotts). During this growing period, plants were pruned several times and were treated with pesticides and fungicides as needed.

Treatments and experimental Design. Saline solutions were prepared by adding $\mathrm{NaCl}, \mathrm{Na}_{2} \mathrm{SO}_{4}, \mathrm{MgCl}_{2} \cdot 2 \mathrm{H}_{2} \mathrm{O}$, $\mathrm{MgSO}_{4} \cdot 7 \mathrm{H}_{2} \mathrm{O}$, and $\mathrm{CaCl}_{2}$ to the nutrient solution $\left(0.5 \mathrm{~g} \cdot \mathrm{L}^{-1}\right.$ of $20 \mathrm{~N}-8.6 \mathrm{P}-16.7 \mathrm{~K}$ ) at various ratios (Table 1 ) to create $\mathrm{Cl}-$ or $\mathrm{SO}_{4}$-dominated saline solutions. The control was the nutrient solution made by adding $0.5 \mathrm{~g} \cdot \mathrm{L}^{-1}$ of $20 \mathrm{~N}-8.6 \mathrm{P}-16.7 \mathrm{~K}$ to tap water. The major ions in the tap water were $\mathrm{Na}, \mathrm{Ca}, \mathrm{Mg}, \mathrm{Cl}$, and
$\mathrm{SO}_{4}$ at $184,52.0,7.5,223.6$, and $105.6 \mathrm{mg} \cdot \mathrm{L}^{-1}$, respectively. Treatments were initiated on 23 March and ended on 15 July (16 weeks). The experiment was a split-plot design with salinity solutions as the main plots and the four rootstocks as the subplots. In each subplot, there were seven plants per rootstock that were randomly placed in the greenhouse.

Five magnetic drive pumps (model 3-MD-MT-HC; Little Giant Co., Oklahoma City, OK) were used to pump the solutions to each container via a drip irrigation system at an average of $3.57 \mathrm{~L}$ per container per irrigation, which resulted in a leaching fraction of $\approx 30 \%$. Irrigation intervals were adjusted according to climate, treatment, and growth stage of the plants, which ranged from every other day to every $4 \mathrm{~d}$ to avoid water stress and to prevent overwatering. In the same treatment, irrigation was based on the rootstock that had the highest water use. During the experimental period, the average air temperature in the greenhouse was $26{ }^{\circ} \mathrm{C} \pm 2.5^{\circ} \mathrm{C}$ during the day and $21{ }^{\circ} \mathrm{C} \pm 2.5^{\circ} \mathrm{C}$ at night. The maximum photosynthetic photo flux ranged from 650 to $1000 \mu \mathrm{mol} \cdot \mathrm{m}^{-2} \cdot \mathrm{s}^{-1}$. The average daily light integral during the experiment was $18.3 \pm 4.0 \mathrm{~mol} \cdot \mathrm{m}^{-2} \cdot \mathrm{d}^{-1}$. All plants were pruned twice in the middle of the experiment to uniform heights (10-12 $\mathrm{cm}$ ) for all shoots across species and treatments and the pruned fresh weights were recorded and dry weights (DW) were determined after oven-drying at $70{ }^{\circ} \mathrm{C}$ to a constant weight.

Measurements. At the end of the experiment, leaf and stem fresh weights were determined by severing the main stem at the substrate surface and separating the leaves and stems. Leaf area was measured using a leaf area meter (LI-3100; LI-COR, Lincoln, NE). Roots were washed free of substrate and their fresh weight was recorded. DW of leaves, stems, and roots were determined by oven-drying at $70{ }^{\circ} \mathrm{C}$ to constant weights. Four samples of roots, stems, and leaves per treatment were collected randomly for analysis of $\mathrm{Na}, \mathrm{Ca}, \mathrm{Mg}, \mathrm{K}$, and $\mathrm{Cl}$ concentrations. Dried tissue was ground with a stainless steel Wiley mill and samples were sent to an analytical laboratory for mineral analysis (SWAT Laboratory, New Mexico State University, Las Cruces). The cation concentrations were determined by U.S. Environmental Protection Agency (EPA) method 200.7 (U.S. Environmental Protection Agency, 1983) and were analyzed on an inductively coupled argon plasma trace analyzer (Thermo Jarrell Ash, Franklin, MA). Chloride was determined by EPA method 300.0 (U.S. Environmental Protection Agency, 1983) and was analyzed using an ion chromatograph (Dionex, Sunnyvale, CA).

Visual quality of the plants was assessed at the end of the experiment based on visual foliar salt damage on all plants. Each plant was given a score of 1 to 5 , where $1=$ over $50 \%$ foliar damage (salt damage: burning and discoloring) or dead; $2=$ moderate $(25 \%-50 \%)$ foliar damage; $3=$ slight $(<25 \%)$ foliage damage; 4 = good quality with little foliar damage (acceptable as landscape performance); 5 = excellent with no foliar damage.

Table 1. Composition and ion concentrations of irrigation treatment solutions to quantify the responses of four rose rootstocks, 'Dr. Huey' (Rosa $\times$ hybrida), $R$. $\times$ fortuniana, $R$. multiflora, and $R$. odorata, to chloride- or sulfate-dominated salinity.

\begin{tabular}{|c|c|c|c|c|c|c|c|}
\hline Treatment $^{2}$ & $\mathrm{EC}\left(\mathrm{dS} \cdot \mathrm{m}^{-1}\right)$ & $\mathrm{Na}\left(\mathrm{mg} \cdot \mathrm{L}^{-1}\right)$ & $\mathrm{Ca}\left(\mathrm{mg} \cdot \mathrm{L}^{-1}\right)$ & $\mathrm{Mg}\left(\mathrm{mg} \cdot \mathrm{L}^{-1}\right)$ & $\mathrm{Cl}\left(\mathrm{mg} \cdot \mathrm{L}^{-1}\right)$ & $\mathrm{SO}_{4}\left(\mathrm{mg} \cdot \mathrm{L}^{-1}\right)$ & $\mathrm{Cl}: \mathrm{SO}_{4}$ (ratio) \\
\hline Control & 1.6 & 184 & 52 & 19 & 224 & 154 & 3.9 \\
\hline $\mathrm{M}-\mathrm{Cl}$ & 3.9 & 193 & 112 & 109 & 664 & 202 & 8.9 \\
\hline $\mathrm{M}-\mathrm{SO}_{4}$ & 3.9 & 225 & 128 & 122 & 227 & 950 & 0.6 \\
\hline $\mathrm{H}-\mathrm{SO}_{4}$ & 7.9 & 768 & 428 & 416 & 749 & 3,245 & 0.6 \\
\hline
\end{tabular}

${ }^{\mathrm{z}} \mathrm{M}=$ moderate salinity, $\mathrm{H}=$ high salinity. 
DAILY ET. The daily ET was determined gravimetrically in the final week on four plants per treatment. Specifically, plants were weighed $\approx 1.5 \mathrm{~h}$ after irrigation when drainage had ceased. The same plants were weighed again in $24 \mathrm{~h}$. The difference in weights equaled the daily ET.

LEACHATE EC. To monitor the root zone salinity, leachate was collected monthly during the experiment on each rootstock (randomly picked up). The EC of leachate was determined using a salinity meter (model B-173; Horiba, Kyoto, Japan).

Data ANALYsis. All data were analyzed by a two-way analysis of variance using PROC GLM. When interaction between salinity and rootstock was significant, multiple comparisons were conducted separately using Student-NewmanKeuls (SNK) at $P=0.05$. When there was no significant interaction, data were pooled across the treatments or rootstocks and the significance of the main effect (salinity or rootstock) was tested by SNK multiple comparisons. The significance of correlation between two parameters was analyzed using PROC CORR. All statistical analyses were performed using SAS (version 9.1.3; SAS Institute, Cary, NC).

\section{Results and Discussion}

LEACHATE EC. In the control treatment, the leachate EC ranged from $1.8 \mathrm{dS} \cdot \mathrm{m}^{-1}$ at the beginning to $2.8 \mathrm{dS} \cdot \mathrm{m}^{-1}$ (EC of irrigation solution at $1.6 \mathrm{dS} \cdot \mathrm{m}^{-1}$ ) at the end of the experiment. In the $\mathrm{M}-\mathrm{Cl}$ and $\mathrm{M}-\mathrm{SO}_{4}$ treatments, the leachate $\mathrm{EC}$ range from 5.0 to $6.2 \mathrm{dS} \cdot \mathrm{m}^{-1}\left(E C\right.$ of irrigation solution at $\left.3.9 \mathrm{dS} \cdot \mathrm{m}^{-1}\right)$, while those in $\mathrm{H}-\mathrm{Cl}$ and $\mathrm{H}-\mathrm{SO}_{4}$ ranged from 8.0 to $12.0 \mathrm{dS} \cdot \mathrm{m}^{-1}$ (EC of irrigation solution at 7.9 to $8.2 \mathrm{dS} \cdot \mathrm{m}^{-1}$, data not shown). No differences were found in leachate $\mathrm{EC}$ between $\mathrm{M}-\mathrm{Cl}$ and $\mathrm{M}-\mathrm{SO}_{4}$ or between $\mathrm{H}-\mathrm{Cl}$ and $\mathrm{H}-\mathrm{SO}_{4}$. In the present study, we did not measure the leachate $\mathrm{EC}$ individually for each rootstock because our previous study indicated no differences in the leachate EC among the rootstocks as long as the EC of irrigation solution was the same (Niu et al., 2008). Large differences in EC between the irrigation solution and leachate were found when peat-based substrates $(100 \%$ Sunshine Mix No. 4) were used; however, the differences were reduced when composted mulch was added to the substrate (Niu and Rodriguez, 2006a, 2006b). In the present study, the substrate was a blend of 1:1 (by volume) ratio of composted mulch and peat-based potting mix. Therefore, the largest differences in EC between the irrigation solution and leachate in the $\mathrm{H}-\mathrm{Cl}$ and $\mathrm{H}-\mathrm{SO}_{4}$ treatments (up to $4 \mathrm{dS} \cdot \mathrm{m}^{-1}$ at the end of the experiment) was relatively small compared with those reported by Niu and Rodriguez (2006a, 2006b) with peat-based mix.

GrowTH. Salinity treatment and rootstock had interactive effects on all growth parameters, indicating that growth response to salinity treatment differed among rootstocks. Shoot DW of 'Dr. Huey' was highest in the control (Fig. 1A), followed by those in treatments $\mathrm{M}-\mathrm{Cl}$ (moderate salinity dominated by chloride) and $\mathrm{M}^{-\mathrm{SO}_{4}}$ (moderate salinity dominated by sulfate). Dominant salt type did not affect shoot DW in this rootstock. Salinity level and dominant salt did not affect the root DW of 'Dr. Huey'. Total DW of 'Dr. Huey' was highest in the control and lowest in $\mathrm{H}-\mathrm{Cl}$. However, no differences in total DW were found in the following pairs: control and $\mathrm{M}_{-} \mathrm{SO}_{4}$, $\mathrm{M}-\mathrm{Cl}$ and $\mathrm{M}-\mathrm{SO}_{4}, \mathrm{M}-\mathrm{Cl}$ and $\mathrm{H}-\mathrm{SO}_{4}$, and $\mathrm{H}-\mathrm{Cl}$ and $\mathrm{H}-\mathrm{SO}_{4}$.

For $R$. $\times$ fortuniana, shoot DW and total DW were similar between the control and $\mathrm{M}-\mathrm{SO}_{4}$ and between $\mathrm{M}-\mathrm{Cl}$ and $\mathrm{H}-\mathrm{SO}_{4}$ (Fig. 1B). H-Cl had the lowest shoot and total DW. Root DW of
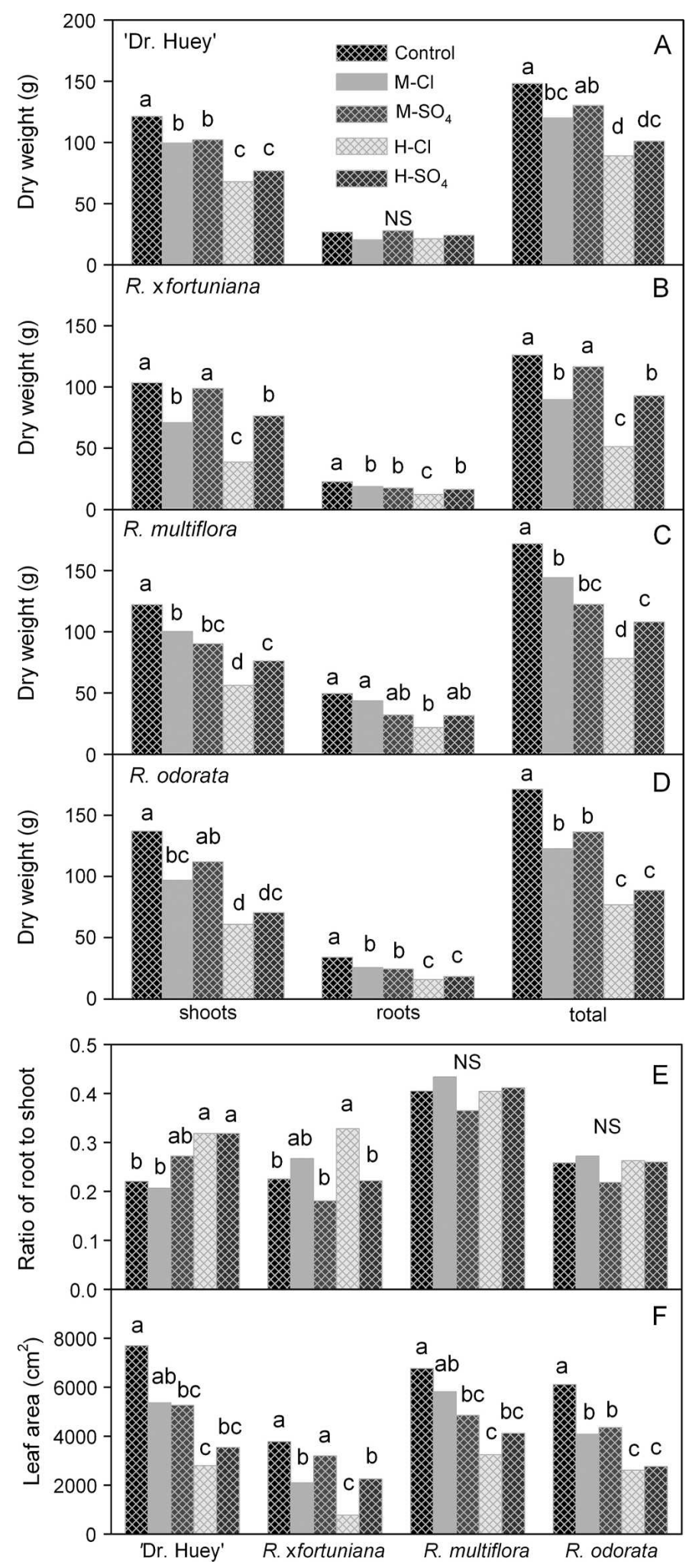

Fig. 1. Dry weight of 'Dr. Huey' (Rosa $\times$ hybrida), R. ×fortuniana, R. multiflora, and $R$. odorata irrigated with saline solutions at various salinities with dominant salt of chloride or sulfate. Means of the same plant part with same letters are not significantly different among the treatments tested by StudentNewman-Keuls at $P=0.05$. NS = non-significant, $\mathrm{M}=$ moderate salinity, $\mathrm{H}=$ high salinity. 
R. $\times$ fortuniana was highest in the control and lowest in $\mathrm{H}-\mathrm{Cl}$. $\mathrm{M}-\mathrm{Cl}, \mathrm{M}-\mathrm{SO}_{4}$, and $\mathrm{H}-\mathrm{SO}_{4}$ had similar root DW. At moderate and high salinities, chloride-dominated salinities ( $\mathrm{M}-\mathrm{Cl}$ and $\mathrm{H}-\mathrm{Cl})$ led to a greater growth reduction in $R$. $\times$ fortuniana than the corresponding sulfate-dominated treatments.

Shoot and total DW of $R$. multiflora was highest in the control and lowest in $\mathrm{H}-\mathrm{Cl}$ (Fig. 1C). There were no differences in shoot and total DW between $\mathrm{M}-\mathrm{Cl}$ and $\mathrm{M}-\mathrm{SO}_{4}$ and between $\mathrm{M}_{-} \mathrm{SO}_{4}$ and $\mathrm{H}-\mathrm{SO}_{4}$. $\mathrm{H}-\mathrm{Cl}$ had the lowest shoot and total DW. Root DW was similar in the control, $\mathrm{M}-\mathrm{Cl}, \mathrm{M}-\mathrm{SO}_{4}$, and $\mathrm{H}-\mathrm{SO}_{4}$ and among $\mathrm{M}_{-} \mathrm{SO}_{4}, \mathrm{H}-\mathrm{Cl}$, and $\mathrm{H}-\mathrm{SO}_{4}$. Therefore, similar to $R$. $\times$ fortuniana, saline solutions at high salinity dominated by chloride led to more growth reduction in R. multiflora.

Shoot DW of $R$. odorata was highest in the control, but no differences were found in the following pairs: control and $\mathrm{M}$ $\mathrm{SO}_{4}, \mathrm{M}-\mathrm{Cl}$ and $\mathrm{M}-\mathrm{SO}_{4}, \mathrm{M}-\mathrm{Cl}$ and $\mathrm{H}-\mathrm{SO}_{4}$, and $\mathrm{H}-\mathrm{Cl}$ and $\mathrm{H}-\mathrm{SO}_{4}$ (Fig. 1D). Root and total DW were highest in the control, followed by $\mathrm{M}-\mathrm{Cl}$ and $\mathrm{M}-\mathrm{SO}_{4}$, and lowest in $\mathrm{H}-\mathrm{Cl}$ and $\mathrm{H}-\mathrm{SO}_{4}$. That is, the type of dominant salt did not affect the root and total DW of $R$. odorata.

Root-to-shoot ratio was affected by salinity treatment and rootstock (Fig. 1E), and the interaction between salinity and rootstock was significant. In 'Dr. Huey', the control and $\mathrm{M}-\mathrm{Cl}$ had the lowest root-to-shoot ratio and $\mathrm{H}-\mathrm{Cl}$ and $\mathrm{H}-\mathrm{SO}_{4}$ had the highest root-to-shoot ratio. However, there were no differences in the ratio among the control, $\mathrm{M}-\mathrm{Cl}$, and $\mathrm{M}-\mathrm{SO}_{4}$ and among $\mathrm{M}-$ $\mathrm{SO}_{4}, \mathrm{H}-\mathrm{Cl}$, and $\mathrm{H}-\mathrm{SO}_{4}$. In $R$. $\times$ fortuniana, root-to-shoot ratio was highest in $\mathrm{H}-\mathrm{Cl}$, but no differences were found between $\mathrm{M}$ $\mathrm{Cl}$ and $\mathrm{H}-\mathrm{Cl}$, and among the control, $\mathrm{M}-\mathrm{Cl}, \mathrm{M}-\mathrm{SO}_{4}$, and $\mathrm{H}-\mathrm{SO}_{4}$. The increased root-to-shoot ratio was caused by greater growth reduction in shoot than in root in both rootstocks. In $R$. multiflora and $R$. odorata, the salinity treatment did not affect the root-to-shoot ratio, indicating that salinity treatments had similar growth reductions in shoots and roots.

Salinity treatments affected the leaf area of 'Dr. Huey' and R. multiflora similarly: leaf area was highest in the control, but no differences were found between the control and $\mathrm{M}-\mathrm{Cl}$, or among $\mathrm{M}-\mathrm{Cl}, \mathrm{M}-\mathrm{SO}_{4}$, and $\mathrm{H}-\mathrm{SO}_{4}$, or $\mathrm{M}-\mathrm{SO}_{4}, \mathrm{H}-\mathrm{Cl}$, and $\mathrm{H}-\mathrm{SO}_{4}$ (Fig. 1F). For $R$. xfortuniana and $R$. odorata, the results for leaf area were similar to those of shoot DW.

There were no interactive effects between salinity treatment and rootstock on pruned shoot DW, and no differences were found among rootstocks (data not shown). In the first pruned shoot DW, high salinity led to lower shoot DW, but dominant salt type did not affect the pruned shoot DW. No differences in the second pruned shoot DW among salinity treatments were found.

The effect of dominant salt type on plant growth varied with rootstock and salinity. At moderate salinity dominated by sulfate, the reduction in total DW compared with the control was highest in $R$. multiflora (29\%), followed by $R$. odorata $(20 \%)$, 'Dr. Huey' (12\%), and R. ×fortuniana (8\%). At high salinity dominated by sulfate, the reduction in total DW compared with the control was highest in $R$. odorata (48\%), followed by $R$. multiflora (37\%), 'Dr. Huey' (32\%), and $R$. $\times$ fortuniana $(26 \%)$. At moderate and high salinity dominated by chloride, the growth reduction was highest in $R$. $\times$ fortuniana, followed by similar reductions in $R$. odorata and $R$. multiflora. Therefore, based on growth, $R$. xfortuniana was the most tolerant to salinity dominated by sulfate, followed by 'Dr. Huey', R. multiflora, and R. odorata in descending order. However, $R$. $\times$ fortuniana was the least tolerant to salinity when chloride was the dominant salt. Regardless of rootstock, the growth reduction was greater in chloride-dominated than sulfate-dominated salinities except for $R$. multiflora at moderate salinity. Similarly, more negative effects of chloride versus sulfate salinity on growth have been reported on chickpea (Manchanda and Sharma, 1989), jack pine (Pinus banksiana Lamb.) (Franklin et al., 2002), lucerne (Medicago sativa L.) (Rogers et al., 1998), siberian larch (Carter, 1980), and sweet pepper (Navarro et al., 2002). In alfalfa (Medicago sativa L.), chloride and sulfate salinity at equal EC had similar reduction in shoot DW (Soltanpour et al., 1999). However, many crops are generally more tolerant to sulfate salinity than chloride salinity (Grattan and Grieve, 1999).

Visual Quality. At moderate salinities ( $\mathrm{M}-\mathrm{Cl}$ and $\mathrm{M}-\mathrm{SO}_{4}$ ), all rootstocks had scores above 4.5 , an acceptable rating for aesthetic appearance in a landscape setting (Table 2). At high salinities $\left(\mathrm{H}-\mathrm{Cl}\right.$ and $\left.\mathrm{H}-\mathrm{SO}_{4}\right)$, the appearance of all rootstocks declined with typical salt damage such as leaf burn and necrosis on lower, older leaves. In addition, chloride-dominated salinity led to a lower visual quality of all rootstocks, especially in $R$. $\times$ fortuniana. Similarly, seedlings of siberian larch (Carter, 1980) and jack pine (Franklin et al., 2002) had more salt injury when exposed to chloride salinity in comparison with sulfate salinity.

DaILY ET. Rootstock and salinity affected daily ET per container. No interactive effect between salinity and rootstock was found on daily ET per unit leaf area or per container. Therefore, data were pooled across salinity treatments or rootstocks (Fig. 2). Daily ET per unit leaf area was higher in $R$. Xfortuniana, but no differences were observed among the other three rootstocks. This was due to smaller total leaf area in $R$. $\times$ fortuniana and a smaller canopy, which may result in high evaporation from the substrate. 'Dr. Huey' and R. multiflora had higher daily ET per container, but no differences were found among 'Dr. Huey', $R$. multiflora, and $R$. odorata and between $R$. ×fortuniana and $R$. odorata. When pooled across rootstocks, daily ET was highest in the control, followed by

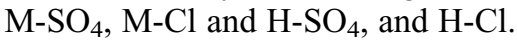

ION UPTAKE. Concentrations of $\mathrm{Ca}$ in 'Dr. Huey' were highest in leaves and lowest in stems (Table 3). The effects of salinity level and dominant salts on $\mathrm{Ca}$ concentration were erratic. For example, leaf $\mathrm{Ca}$ concentrations in $\mathrm{M}-\mathrm{Cl}$ and $\mathrm{H}-\mathrm{Cl}$ were higher than those in the other treatments, while root $\mathrm{Ca}$ concentration was highest in $\mathrm{H}_{-} \mathrm{SO}_{4}$, with no differences among the other treatments. $\mathrm{Mg}$ and $\mathrm{Cl}$ concentrations in 'Dr. Huey' generally increased with their corresponding concentrations in

Table 2. Visual scores of four rose rootstocks, 'Dr. Huey' (Rosa $\times$ hybrida), $R . \times$ fortuniana, $R$. multiflora, and $R$. odorata, irrigated with saline solutions at various salinities dominated by chloride or sulfate salt for 16 weeks.

\begin{tabular}{|c|c|c|c|c|c|}
\hline \multirow[b]{3}{*}{ Rootstock } & \multirow[b]{3}{*}{ Control } & \multicolumn{4}{|c|}{ Treatment $^{z}$} \\
\hline & & $\mathrm{M}-\mathrm{Cl}$ & $\mathrm{M}-\mathrm{SO}_{4}$ & $\mathrm{H}-\mathrm{Cl}$ & $\mathrm{H}-\mathrm{SO}_{4}$ \\
\hline & & \multicolumn{4}{|c|}{--------Visual score $(1-5 \text { scale })^{\mathrm{y}}$------- } \\
\hline 'Dr. Huey' & 5.0 & 4.9 & 5.0 & 4.2 & 4.8 \\
\hline R. $\times$ fortuniana & 5.0 & 4.8 & 5.0 & 2.2 & 4.6 \\
\hline R. multiflora & 5.0 & 5.0 & 5.0 & 4.5 & 4.6 \\
\hline R. odorata & 5.0 & 4.6 & 4.9 & 4.3 & 4.5 \\
\hline
\end{tabular}

${ }^{\mathrm{z}} \mathrm{M}=$ moderate salinity, $\mathrm{H}=$ high salinity.

${ }^{\mathrm{y}} 1=$ over $50 \%$ foliar damage or dead, $2=$ moderate $(25 \%-50 \%)$ foliar damage, $3=$ slight $(<25 \%)$ foliage damage, $4=$ good quality with little foliar damage, $5=$ excellent with no foliar damage. 

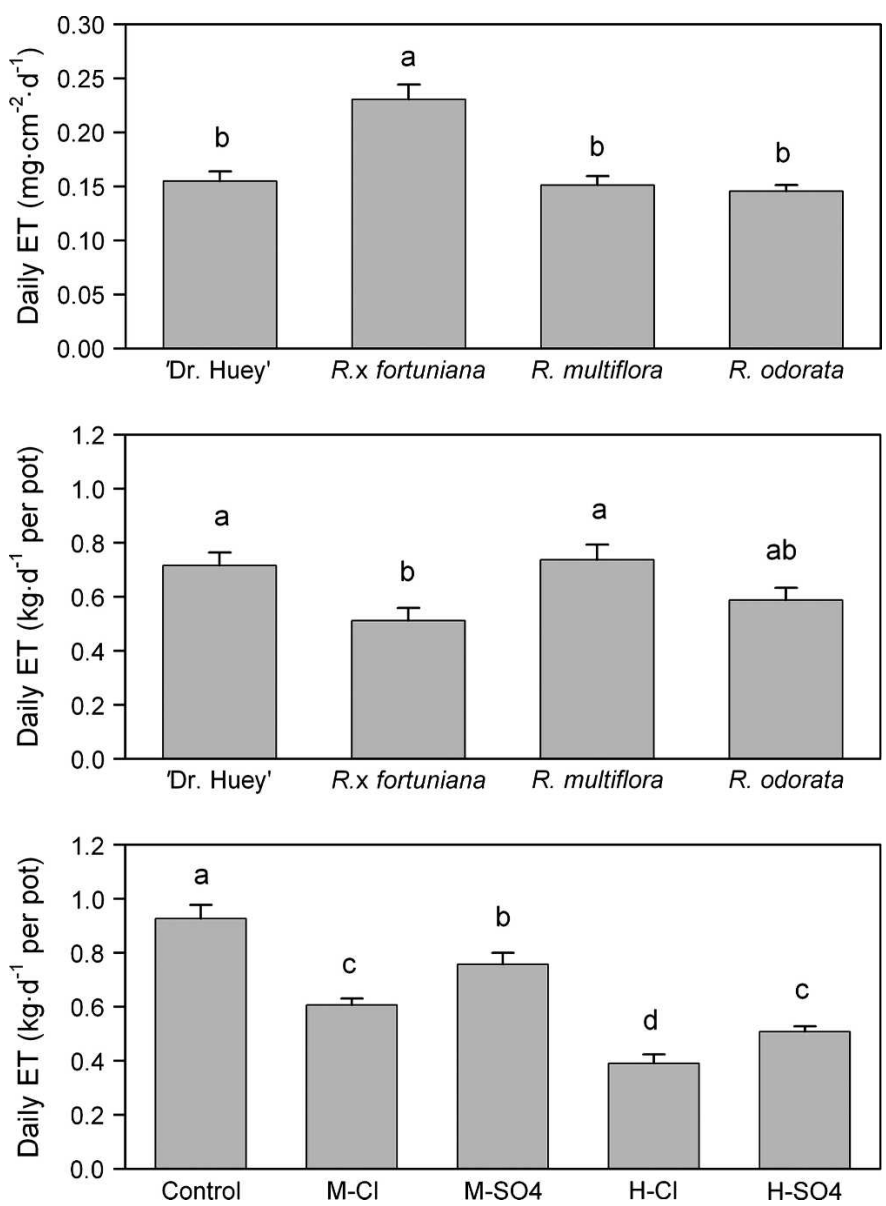

Fig. 2. Daily evapotranspiration rate (ET) per unit leaf or per pot of 'Dr. Huey' (Rosa $\times$ hybrida), $R$. $\times$ fortuniana, $R$. multiflora, and $R$. odorata pooled across treatments or rootstocks. Means with same letters are not significantly different tested by Student-Newman-Keuls at $P=0.05$. Vertical bars refer to $\mathrm{SE} ; \mathrm{M}=$ moderate salinity, $\mathrm{H}=$ high salinity.

the irrigation solutions (Table 1 and Table $3 ; P<0.0001$ for all correlations except for $\mathrm{Cl}$ in the solution vs. root $\mathrm{Cl}$, where $P=0.03$ ). Leaf $\mathrm{Cl}$ concentration in $\mathrm{H}-\mathrm{Cl}$ was highest and those in $\mathrm{M}-\mathrm{Cl}$ and $\mathrm{H}-\mathrm{SO}_{4}$ were $50 \%$ lower. Root Na concentration was three to five times higher than those in stems and leaves. This may indicate that 'Dr. Huey' limited the amount of $\mathrm{Na}$ transport to shoots. Root Na was highest in $\mathrm{H}_{-} \mathrm{SO}_{4}$, followed by $\mathrm{H}-\mathrm{Cl}$. No differences were found between $\mathrm{M}-\mathrm{Cl}$ and $\mathrm{M}-\mathrm{SO}_{4}$ and between the control and $\mathrm{M}_{-} \mathrm{SO}_{4}$. No differences were found in $\mathrm{K}$ concentrations in the plant tissue except for the roots where $\mathrm{K}$ concentrations in $\mathrm{M}_{-} \mathrm{SO}_{4}$ and $\mathrm{H}-\mathrm{SO}_{4}$ were slightly lower than the other treatments.

In $R$. ×fortuniana, salinity treatment did not substantially affect $\mathrm{Ca}$ concentration (Table 4). $\mathrm{Mg}$ and $\mathrm{Cl}$ concentrations in the leaves and stems increased with their corresponding ion concentrations in the irrigation solutions $(P<0.0001)$ except for root $\mathrm{Cl}$ concentration. However, $\mathrm{Cl}$ in the roots did not correlate with $\mathrm{Cl}$ in the solution. Similar to 'Dr. Huey', leaf $\mathrm{Cl}$ concentration in $R$. xfortuniana in $\mathrm{H}-\mathrm{Cl}$ was highest and was three times that in $\mathrm{M}-\mathrm{Cl}$ and $\mathrm{H}-\mathrm{SO}_{4}$. Root Na concentration was six times higher than that in leaves or stems. $\mathrm{K}$ concentrations in the stems and roots tended to decrease with increasing salinity.

In R. multiflora, no clear trends on the effects of salinity level and dominant salt on tissue $\mathrm{Ca}$ concentrations were found
Table 3. Ion concentrations of leaves, stems, and roots of 'Dr. Huey' $($ Rosa $\times$ hybrida $)$ irrigated with saline solutions at various salinities dominated by chloride or sulfate salt for 16 weeks.

\begin{tabular}{|c|c|c|c|c|c|}
\hline Treatment $^{\mathrm{z}}$ & $\begin{array}{c}\mathrm{Ca} \\
\left(\mathrm{mg} \cdot \mathrm{g}^{-1}\right)\end{array}$ & $\begin{array}{c}\mathrm{Mg} \\
\left(\mathrm{mg} \cdot \mathrm{g}^{-1}\right)\end{array}$ & $\begin{array}{c}\mathrm{K} \\
\left(\mathrm{mg} \cdot \mathrm{g}^{-1}\right)\end{array}$ & $\begin{array}{c}\mathrm{Na} \\
\left(\mathrm{mg} \cdot \mathrm{g}^{-1}\right)\end{array}$ & $\begin{array}{c}\mathrm{Cl} \\
\left(\mathrm{mg} \cdot \mathrm{g}^{-1}\right)\end{array}$ \\
\hline \multicolumn{6}{|c|}{ Leaves } \\
\hline Control & $12.1 \mathrm{~b}^{\mathrm{y}}$ & $2.5 \mathrm{~d}$ & $17.4 \mathrm{a}$ & $0.4 \mathrm{c}$ & $6.2 \mathrm{~d}$ \\
\hline $\mathrm{M}-\mathrm{Cl}$ & $16.1 \mathrm{a}$ & $3.8 \mathrm{~b}$ & $17.4 \mathrm{a}$ & $0.5 \mathrm{bc}$ & $15.3 \mathrm{~b}$ \\
\hline $\mathrm{M}-\mathrm{SO}_{4}$ & $13.0 \mathrm{~b}$ & $3.3 \mathrm{c}$ & $17.4 \mathrm{a}$ & $0.5 \mathrm{bc}$ & $9.4 \mathrm{c}$ \\
\hline $\mathrm{H}-\mathrm{Cl}$ & $17.4 \mathrm{a}$ & $4.5 \mathrm{a}$ & $19.1 \mathrm{a}$ & $1.0 \mathrm{a}$ & $28.9 \mathrm{a}$ \\
\hline $\mathrm{H}-\mathrm{SO}_{4}$ & $12.0 \mathrm{~b}$ & $4.6 \mathrm{a}$ & $17.3 \mathrm{a}$ & $0.8 \mathrm{ab}$ & $15.2 \mathrm{~b}$ \\
\hline \multicolumn{6}{|c|}{ Stems } \\
\hline Control & $7.7 \mathrm{ab}$ & $1.7 \mathrm{c}$ & $7.8 \mathrm{a}$ & $0.6 \mathrm{c}$ & $3.2 \mathrm{c}$ \\
\hline $\mathrm{M}-\mathrm{Cl}$ & $7.8 \mathrm{ab}$ & $2.2 \mathrm{bc}$ & $7.0 \mathrm{a}$ & $0.8 \mathrm{bc}$ & $5.3 \mathrm{~b}$ \\
\hline $\mathrm{M}-\mathrm{SO}_{4}$ & $6.4 \mathrm{~b}$ & $1.8 \mathrm{c}$ & $7.5 \mathrm{a}$ & $0.8 \mathrm{bc}$ & $3.3 \mathrm{c}$ \\
\hline $\mathrm{H}-\mathrm{Cl}$ & $9.5 \mathrm{a}$ & $2.9 \mathrm{a}$ & $7.1 \mathrm{a}$ & $0.9 \mathrm{~b}$ & $7.9 \mathrm{a}$ \\
\hline \multicolumn{6}{|c|}{ Roots } \\
\hline Control & $11.0 \mathrm{~b}$ & $2.1 \mathrm{c}$ & $6.3 \mathrm{a}$ & $2.1 \mathrm{~d}$ & $6.4 \mathrm{~b}$ \\
\hline $\mathrm{M}-\mathrm{Cl}$ & $10.0 \mathrm{~b}$ & $2.6 \mathrm{~b}$ & $6.7 \mathrm{a}$ & $2.8 \mathrm{c}$ & $9.1 \mathrm{ab}$ \\
\hline $\mathrm{M}-\mathrm{SO}_{4}$ & $9.7 \mathrm{~b}$ & $2.4 \mathrm{bc}$ & $5.4 \mathrm{~b}$ & $2.5 \mathrm{dc}$ & $9.7 \mathrm{ab}$ \\
\hline $\mathrm{H}-\mathrm{Cl}$ & $9.7 \mathrm{~b}$ & $3.0 \mathrm{a}$ & $6.1 \mathrm{a}$ & $3.4 \mathrm{~b}$ & $10.9 \mathrm{a}$ \\
\hline $\mathrm{H}-\mathrm{SO}_{4}$ & $22.5 \mathrm{a}$ & $3.2 \mathrm{a}$ & $5.0 \mathrm{~b}$ & $4.1 \mathrm{a}$ & $9.7 \mathrm{ab}$ \\
\hline
\end{tabular}

${ }^{\mathrm{z}} \mathrm{M}=$ moderate salinity, $\mathrm{H}=$ high salinity.

${ }^{y}$ Means within each plant part followed by the same letters are not significantly different tested by Student-Newman-Keuls multiple comparison at $P=0.05$.

Table 4. Ion concentrations of leaves, stems, and roots of Rosa $\times$ fortuniana irrigated with saline solutions at various salinities dominated by chloride or sulfate salt for 16 weeks.

\begin{tabular}{|c|c|c|c|c|c|}
\hline Treatment ${ }^{z}$ & $\begin{array}{c}\mathrm{Ca} \\
\left(\mathrm{mg} \cdot \mathrm{g}^{-1}\right)\end{array}$ & $\begin{array}{c}\mathrm{Mg} \\
\left(\mathrm{mg} \cdot \mathrm{g}^{-1}\right)\end{array}$ & $\begin{array}{c}\mathrm{K} \\
\left(\mathrm{mg} \cdot \mathrm{g}^{-1}\right)\end{array}$ & $\begin{array}{c}\mathrm{Na} \\
\left(\mathrm{mg} \cdot \mathrm{g}^{-1}\right)\end{array}$ & $\begin{array}{c}\mathrm{Cl} \\
\left(\mathrm{mg} \cdot \mathrm{g}^{-1}\right)\end{array}$ \\
\hline \multicolumn{6}{|c|}{ Leaves } \\
\hline Control & $14.0 \mathrm{~b}^{\mathrm{y}}$ & $2.4 \mathrm{~d}$ & $16.3 \mathrm{a}$ & $0.4 \mathrm{~b}$ & $6.9 \mathrm{~b}$ \\
\hline $\mathrm{M}-\mathrm{Cl}$ & $15.6 \mathrm{ab}$ & $3.2 \mathrm{c}$ & $14.4 \mathrm{~b}$ & $0.3 \mathrm{~b}$ & $11.9 \mathrm{~b}$ \\
\hline $\mathrm{M}-\mathrm{SO}_{4}$ & $14.0 \mathrm{~b}$ & $3.1 \mathrm{c}$ & $12.4 \mathrm{c}$ & $0.3 \mathrm{~b}$ & $7.4 \mathrm{~b}$ \\
\hline $\mathrm{H}-\mathrm{Cl}$ & $16.5 \mathrm{a}$ & $3.8 \mathrm{~b}$ & $17.4 \mathrm{a}$ & $1.1 \mathrm{a}$ & $29.5 \mathrm{a}$ \\
\hline $\mathrm{H}-\mathrm{SO}_{4}$ & $13.8 \mathrm{~b}$ & $4.1 \mathrm{a}$ & $11.1 \mathrm{~d}$ & $0.3 \mathrm{~b}$ & $9.5 \mathrm{~b}$ \\
\hline \multicolumn{6}{|c|}{ Stems } \\
\hline Control & $8.7 \mathrm{ab}$ & $1.5 \mathrm{c}$ & $10.1 \mathrm{a}$ & $0.2 \mathrm{~b}$ & $4.5 \mathrm{c}$ \\
\hline $\mathrm{M}-\mathrm{Cl}$ & $9.2 \mathrm{ab}$ & $1.9 \mathrm{ab}$ & $8.8 \mathrm{~b}$ & $0.3 \mathrm{~b}$ & $8.0 \mathrm{~b}$ \\
\hline $\mathrm{M}-\mathrm{SO}_{4}$ & $8.0 \mathrm{~b}$ & $1.9 \mathrm{~b}$ & $8.3 \mathrm{~b}$ & $0.3 \mathrm{~b}$ & $4.1 \mathrm{c}$ \\
\hline $\mathrm{H}-\mathrm{Cl}$ & $10.8 \mathrm{a}$ & $2.3 \mathrm{a}$ & $5.5 \mathrm{c}$ & $1.1 \mathrm{a}$ & $10.3 \mathrm{a}$ \\
\hline $\mathrm{H}-\mathrm{SO}_{4}$ & $7.2 \mathrm{~b}$ & $2.3 \mathrm{a}$ & $8.0 \mathrm{~b}$ & $0.4 \mathrm{~b}$ & $5.8 \mathrm{c}$ \\
\hline \multicolumn{6}{|c|}{ Roots } \\
\hline Control & $11.2 \mathrm{a}$ & $2.6 \mathrm{~b}$ & $7.4 \mathrm{a}$ & $2.5 \mathrm{a}$ & $8.2 \mathrm{~b}$ \\
\hline $\mathrm{M}-\mathrm{Cl}$ & $10.2 \mathrm{ab}$ & $3.4 \mathrm{a}$ & $6.1 \mathrm{ab}$ & $2.8 \mathrm{a}$ & $11.8 \mathrm{a}$ \\
\hline $\mathrm{M}-\mathrm{SO}_{4}$ & $10.0 \mathrm{ab}$ & $3.4 \mathrm{a}$ & $6.3 \mathrm{ab}$ & $3.0 \mathrm{a}$ & $10.4 \mathrm{ab}$ \\
\hline $\mathrm{H}-\mathrm{Cl}$ & $8.7 \mathrm{~b}$ & $3.4 \mathrm{a}$ & $3.2 \mathrm{c}$ & $3.2 \mathrm{a}$ & $11.8 \mathrm{a}$ \\
\hline $\mathrm{H}-\mathrm{SO}_{4}$ & $8.2 \mathrm{~b}$ & $3.4 \mathrm{a}$ & $5.1 \mathrm{~b}$ & $3.2 \mathrm{a}$ & $13.2 \mathrm{a}$ \\
\hline
\end{tabular}

${ }^{\mathrm{z}} \mathrm{M}=$ moderate salinity, $\mathrm{H}=$ high salinity.

${ }^{\mathrm{y}}$ Means within each plant part followed by the same letters are not significantly different tested by Student-Newman-Keuls multiple comparison at $P=0.05$.

(Table 5). $\mathrm{Mg}$ and $\mathrm{Cl}$ concentrations in all plant parts increased with their corresponding ion concentrations in the solutions. Leaf $\mathrm{Cl}$ concentration was highest in $\mathrm{H}-\mathrm{Cl}$ and was about double the concentrations in $\mathrm{M}-\mathrm{Cl}$ and $\mathrm{H}-\mathrm{SO}_{4}$. In all plant parts, 
Table 5. Ion concentrations of leaves, stems, and roots of Rosa multiflora irrigated with saline solutions at various salinities dominated by chloride or sulfate salt for 16 weeks.

\begin{tabular}{|c|c|c|c|c|c|}
\hline Treatment $^{\mathrm{z}}$ & $\begin{array}{c}\mathrm{Ca} \\
\left(\mathrm{mg} \cdot \mathrm{g}^{-1}\right)\end{array}$ & $\begin{array}{c}\mathrm{Mg} \\
\left(\mathrm{mg} \cdot \mathrm{g}^{-1}\right)\end{array}$ & $\begin{array}{c}\mathrm{K} \\
\left(\mathrm{mg} \cdot \mathrm{g}^{-1}\right)\end{array}$ & $\begin{array}{c}\mathrm{Na} \\
\left(\mathrm{mg} \cdot \mathrm{g}^{-1}\right)\end{array}$ & $\begin{array}{c}\mathrm{Cl} \\
\left(\mathrm{mg} \cdot \mathrm{g}^{-1}\right)\end{array}$ \\
\hline \multicolumn{6}{|c|}{ Leaves } \\
\hline Control & $14.3 \mathrm{ab}^{\mathrm{y}}$ & $2.6 \mathrm{c}$ & $24.5 \mathrm{a}$ & $0.5 \mathrm{~b}$ & $10.4 \mathrm{c}$ \\
\hline $\mathrm{M}-\mathrm{Cl}$ & $15.4 \mathrm{ab}$ & $4.2 \mathrm{~b}$ & $20.2 \mathrm{~b}$ & $0.3 \mathrm{~b}$ & $16.4 \mathrm{~b}$ \\
\hline $\mathrm{M}-\mathrm{SO}_{4}$ & $13.5 \mathrm{~b}$ & $4.2 \mathrm{~b}$ & $19.8 \mathrm{~b}$ & $0.4 \mathrm{~b}$ & $9.9 \mathrm{c}$ \\
\hline $\mathrm{H}-\mathrm{Cl}$ & $15.9 \mathrm{a}$ & $6.2 \mathrm{a}$ & $19.3 \mathrm{~b}$ & $0.4 \mathrm{~b}$ & $28.2 \mathrm{a}$ \\
\hline $\mathrm{H}-\mathrm{SO}_{4}$ & $10.8 \mathrm{c}$ & $6.4 \mathrm{a}$ & $21.1 \mathrm{~b}$ & $0.9 \mathrm{a}$ & $14.9 \mathrm{~b}$ \\
\hline \multicolumn{6}{|c|}{ Stems } \\
\hline Control & $8.3 \mathrm{ab}$ & $1.7 \mathrm{c}$ & $10.8 \mathrm{a}$ & $0.3 \mathrm{~b}$ & $2.3 \mathrm{c}$ \\
\hline $\mathrm{M}-\mathrm{Cl}$ & $8.4 \mathrm{ab}$ & $2.6 \mathrm{~b}$ & $8.2 \mathrm{~b}$ & $0.3 \mathrm{~b}$ & $4.5 \mathrm{~b}$ \\
\hline $\mathrm{M}-\mathrm{SO}_{4}$ & $7.2 \mathrm{bc}$ & $2.6 \mathrm{~b}$ & $9.0 \mathrm{ab}$ & $0.3 \mathrm{~b}$ & $2.9 \mathrm{c}$ \\
\hline $\mathrm{H}-\mathrm{Cl}$ & $10.0 \mathrm{a}$ & $4.0 \mathrm{a}$ & $7.3 \mathrm{~b}$ & $1.1 \mathrm{~b}$ & $7.3 \mathrm{a}$ \\
\hline \multicolumn{6}{|c|}{ Roots } \\
\hline Control & $13.8 \mathrm{ab}$ & $2.7 \mathrm{~b}$ & $5.4 \mathrm{a}$ & $3.6 \mathrm{~b}$ & $7.7 \mathrm{c}$ \\
\hline $\mathrm{M}-\mathrm{Cl}$ & $10.2 \mathrm{ab}$ & $3.1 \mathrm{ab}$ & $3.8 \mathrm{~b}$ & $4.4 \mathrm{ab}$ & $11.6 \mathrm{~b}$ \\
\hline $\mathrm{M}-\mathrm{SO}_{4}$ & $13.9 \mathrm{ab}$ & $3.4 \mathrm{ab}$ & $3.9 \mathrm{~b}$ & $4.8 \mathrm{ab}$ & $9.5 \mathrm{bc}$ \\
\hline $\mathrm{H}-\mathrm{Cl}$ & $8.9 \mathrm{~b}$ & $3.3 \mathrm{ab}$ & $3.4 \mathrm{~b}$ & $5.3 \mathrm{a}$ & $14.9 \mathrm{a}$ \\
\hline $\mathrm{H}-\mathrm{SO}_{4}$ & $16.8 \mathrm{a}$ & $4.0 \mathrm{a}$ & $3.1 \mathrm{~b}$ & $5.9 \mathrm{a}$ & $10.2 \mathrm{bc}$ \\
\hline
\end{tabular}

${ }^{\mathrm{z}} \mathrm{M}=$ moderate salinity, $\mathrm{H}=$ high salinity.

${ }^{\mathrm{y}}$ Means within each plant part followed by the same letters are not significantly different tested by Student-Newman-Keuls multiple comparison at $P=0.05$.

$\mathrm{K}$ concentrations in the control were higher than in the other treatments except for the stems, where no difference was observed between the control and $\mathrm{M}-\mathrm{SO}_{4}$. Similar to other rootstocks, root Na concentrations were much higher than those in stems or leaves. However, root $\mathrm{Na}$ concentration in $R$. multiflora was higher than those in other rootstocks.

Concentrations of $\mathrm{Ca}$ in $\mathrm{R}$. odorata were similar among the treatments in all parts except for the leaf $\mathrm{Ca}$ in $\mathrm{H}-\mathrm{SO}_{4}$, which was lower than the other treatments (Table 6). Except for root $\mathrm{Mg}, \mathrm{Mg}$ and $\mathrm{Cl}$ concentrations in all plant parts increased with their corresponding ion concentrations in the solutions. Leaf $\mathrm{Cl}$ concentration in $\mathrm{H}-\mathrm{Cl}\left(26 \mathrm{mg} \cdot \mathrm{g}^{-1}\right)$ was slightly lower than those in the other rootstocks $\left(29 \mathrm{mg} \cdot \mathrm{g}^{-1}\right)$. Na concentrations in all plant parts were unaffected by the type of dominant salt, and were highest in the roots, followed by the stems. Compared with other rootstocks, $\mathrm{Na}$ concentrations in stems and leaves were higher in $R$. odorata.

The restriction of ion uptake by the roots and the prevention of ion accumulation in the shoots are important mechanisms in salt tolerance of glycophytes. In the current study, all rootstocks had limited $\mathrm{Na}$ uptake compared with $\mathrm{Cl}$, but this ability varied among rootstocks. Compared with the absolute amount of $\mathrm{Na}$ and $\mathrm{Cl}$ uptake, which was calculated by multiplying the DW of the plant part by $\mathrm{Na}$ or $\mathrm{Cl}$ concentration, we found that R. multiflora had the highest $\mathrm{Na}$ uptake per plant $(1090 \mathrm{mg})$, followed by $R$. odorata (1073 mg), 'Dr. Huey' (684 mg), and $R$. $\times$ fortuniana $(402 \mathrm{mg})$. Similar to $\mathrm{Na}, R$. multiflora had the highest $\mathrm{Cl}$ uptake $(5985 \mathrm{mg})$, followed by 'Dr. Huey' $(5245 \mathrm{mg}), R$. odorata $(5186 \mathrm{mg})$, and $R$. Xfortuniana (3963 mg). Rosa multiflora accumulated a higher amount of $\mathrm{Na}$ but retained $75 \%$ of the $\mathrm{Na}$ in the roots, while $R$. odorata had $57 \%$ of the $\mathrm{Na}$ in the shoots. In addition, $R$. odorata had lower visual scores in $\mathrm{M}-\mathrm{Cl}$ than $\mathrm{M}-\mathrm{SO}_{4}$, which may be due to the
Table 6. Ion concentrations of leaves, stems, and roots of Rosa odorata irrigated with saline solutions at various salinities dominated by chloride or sulfate salt for 16 weeks.

\begin{tabular}{|c|c|c|c|c|c|}
\hline Treatment $^{z}$ & $\begin{array}{c}\mathrm{Ca} \\
\left(\mathrm{mg} \cdot \mathrm{g}^{-1}\right) \\
\end{array}$ & $\begin{array}{c}\mathrm{Mg} \\
\left(\mathrm{mg} \cdot \mathrm{g}^{-1}\right)\end{array}$ & $\begin{array}{c}\mathrm{K} \\
\left(\mathrm{mg} \cdot \mathrm{g}^{-1}\right) \\
\end{array}$ & $\begin{array}{c}\mathrm{Na} \\
\left(\mathrm{mg} \cdot \mathrm{g}^{-1}\right)\end{array}$ & $\begin{array}{c}\mathrm{Cl} \\
\left(\mathrm{mg} \cdot \mathrm{g}^{-1}\right)\end{array}$ \\
\hline \multicolumn{6}{|c|}{ Leaves } \\
\hline Control & $14.3 \mathrm{a}^{\mathrm{y}}$ & $2.6 \mathrm{c}$ & $20.2 \mathrm{a}$ & $0.2 \mathrm{~b}$ & $8.2 \mathrm{e}$ \\
\hline $\mathrm{M}-\mathrm{Cl}$ & $13.1 \mathrm{a}$ & $3.2 \mathrm{~b}$ & $18.7 \mathrm{~b}$ & $1.2 \mathrm{ab}$ & $17.4 \mathrm{~b}$ \\
\hline $\mathrm{M}-\mathrm{SO}_{4}$ & $12.7 \mathrm{a}$ & $3.2 \mathrm{~b}$ & $16.9 \mathrm{c}$ & $0.5 \mathrm{~b}$ & $10.7 \mathrm{~d}$ \\
\hline $\mathrm{H}-\mathrm{Cl}$ & $13.9 \mathrm{a}$ & $3.9 \mathrm{a}$ & $17.6 \mathrm{bc}$ & $1.7 \mathrm{a}$ & $26.1 \mathrm{a}$ \\
\hline $\mathrm{H}-\mathrm{SO}_{4}$ & $11.1 \mathrm{~b}$ & $4.0 \mathrm{a}$ & $16.6 \mathrm{c}$ & $1.8 \mathrm{a}$ & $12.6 \mathrm{c}$ \\
\hline \multicolumn{6}{|c|}{ Stems } \\
\hline Control & $4.5 \mathrm{a}$ & $1.4 \mathrm{~b}$ & $11.5 \mathrm{a}$ & $0.5 \mathrm{c}$ & $3.4 \mathrm{~d}$ \\
\hline $\mathrm{M}-\mathrm{Cl}$ & $5.6 \mathrm{a}$ & $1.9 \mathrm{ab}$ & $7.0 \mathrm{~b}$ & $2.3 \mathrm{ab}$ & $5.7 \mathrm{bc}$ \\
\hline $\mathrm{M}-\mathrm{SO}_{4}$ & $5.4 \mathrm{a}$ & $1.9 \mathrm{ab}$ & $8.9 \mathrm{ab}$ & $0.9 \mathrm{bc}$ & $4.6 \mathrm{dc}$ \\
\hline $\mathrm{H}-\mathrm{Cl}$ & $6.3 \mathrm{a}$ & $2.5 \mathrm{a}$ & $5.5 \mathrm{~b}$ & $3.1 \mathrm{a}$ & $7.7 \mathrm{a}$ \\
\hline \multicolumn{3}{|c|}{ Roots } & $8.0 \mathrm{~b}$ & $2.5 \mathrm{ab}$ & $6.4 \mathrm{ab}$ \\
\hline Control & $15.0 \mathrm{a}$ & $2.7 \mathrm{~b}$ & $7.0 \mathrm{a}$ & $3.3 \mathrm{a}$ & $5.2 \mathrm{~b}$ \\
\hline $\mathrm{M}-\mathrm{Cl}$ & $11.3 \mathrm{a}$ & $3.4 \mathrm{a}$ & $6.3 \mathrm{a}$ & $3.7 \mathrm{a}$ & $9.8 \mathrm{~b}$ \\
\hline $\mathrm{M}-\mathrm{SO}_{4}$ & $13.5 \mathrm{a}$ & $4.0 \mathrm{a}$ & $6.3 \mathrm{a}$ & $4.3 \mathrm{a}$ & $7.3 \mathrm{~b}$ \\
\hline $\mathrm{H}-\mathrm{Cl}$ & $8.3 \mathrm{a}$ & $3.3 \mathrm{a}$ & $6.6 \mathrm{a}$ & $4.1 \mathrm{a}$ & $13.2 \mathrm{a}$ \\
\hline $\mathrm{H}-\mathrm{SO}_{4}$ & $11.6 \mathrm{a}$ & $3.8 \mathrm{a}$ & $5.0 \mathrm{~b}$ & $4.4 \mathrm{a}$ & $7.5 \mathrm{~b}$ \\
\hline
\end{tabular}

${ }^{\mathrm{z}} \mathrm{M}=$ moderate salinity, $\mathrm{H}=$ high salinity.

${ }^{y}$ Means within each plant part followed by the same letters are not significantly different tested by Student-Newman-Keuls multiple comparison at $P=0.05$.

higher $\mathrm{Na}$ concentrations in the shoots. The salt tolerance mechanism of restricting $\mathrm{Na}$ uptake and transport depends on the rootstock, salinity, and dominant salt type. For example, at high salinities, leaf Na concentrations in $R$. ×fortuniana were higher in chloride-dominated salinity (Table 4), while $R$. multiflora had higher leaf $\mathrm{Na}$ concentration in sulfatedominated salinity (Table 5), which had a slightly higher $\mathrm{Na}$ concentration in the irrigation water (Table 1). In our previous study, stem Na concentration in $R$. odorata was higher than that in the roots (Niu et al., 2008). These results indicate that $R$. odorata has limited ability to prevent $\mathrm{Na}$ transport from the roots to the shoots compared with the other three rootstocks.

The reason why chloride-dominated salinity leads to a larger negative effect on growth and visual quality in most crops might be due to the lower requirement for $\mathrm{Cl}$ or lower tissue $\mathrm{Cl}$ threshold compared with $\mathrm{S}$ or $\mathrm{N}$. The differences in salt damage or $\mathrm{Cl}$ toxicity are mainly related to the differences in sensitivity to excessive $\mathrm{Cl}$ levels in leaf tissue or different thresholds of leaf $\mathrm{Cl}$ levels among genotypes. For example, although $R$. ×fortuniana had a similar high leaf $\mathrm{Cl}$ concentration $\left(29 \mathrm{mg} \cdot \mathrm{g}^{-1}\right)$ to those of other rootstocks, it showed the most severe foliar salt damage at high salinity dominated by chloride. These results indicate that the threshold of tissue $\mathrm{Cl}$ concentration for $R$. $\times$ fortuniana is lower than those for the other three rootstocks. Tolerant crops such as barley (Hordeum vulgare L.), spinach (Spinacia oleracea L.), lettuce (Lactuca sativa L.), and sugar beet (Beta vulgaris L.) did not exhibit a toxic effect at leaf $\mathrm{Cl}$ concentrations of 20 to $30 \mathrm{mg} \cdot \mathrm{g}^{-1}$ (Wu et al., 1995). Some sensitive greenhouse rose genotypes had a threshold as low as $4.5 \mathrm{mg} \cdot \mathrm{g}^{-1}$ (Cabrera and Perdomo, 2003), above which shoot DW started to decrease. Unlike cut flower roses, reduced growth for garden roses may be acceptable as long as the aesthetic appearance is unaffected. In fact, growth suppressants 
may be applied to reduce growth and achieve a more compact habit and to reduce the need for frequent pruning. Thus, growth or yield alone should not be used as a criterion to determine the salinity threshold. One should also be cautious to compare the threshold of irrigation solution EC or threshold of tissue $\mathrm{Na}$ or $\mathrm{Cl}$ toxic levels because plant response to salinity may be altered by factors such as climate and substrate or soil conditions.

\section{Conclusion}

Growth and ion uptake of four rootstocks responded to salinity and dominant salt type differently. Rosa $\times$ fortuniana was the most tolerant rootstock when irrigated with saline solution dominated by sulfate, followed by 'Dr. Huey', $R$. multiflora, and $R$. odorata in descending order. However, $R$. $\times$ fortuniana was the least tolerant rootstock when chloride is dominant in the saline solutions, $R$. odorata was the second least tolerant, and 'Dr. Huey' was the most tolerant. Rosa $\times$ fortuniana and 'Dr. Huey' had higher restriction ability of $\mathrm{Na}$ uptake than the other two rootstocks. It is important to note that the results from this study may be used as a reference for selecting salt-tolerant rose rootstocks for salt-affected areas. Further research is needed to investigate if the relative salt tolerance of the scions grafted or budded onto these rose rootstocks would be consistent with that obtained in this study.

\section{Literature Cited}

Bernstein, N., B.T. Asher, F. Haya, S. Pini, R. Ilona, C. Amram, and I. Marina. 2006. Application of treated wastewater for cultivation of roses (Rosa hybrida) in soil-less culture. Scientia Hort. 108:185-193.

Cabrera, R.I. 2001. Effect of $\mathrm{NaCl}$ salinity and nitrogen fertilizer formulation on yield and nutrient status of roses. Acta Hort. 547:255-260. Cabrera, R.I. 2002. Rose yield, dry matter partitioning and nutrient status responses to rootstock selection. Scientia Hort. 95:75-83.

Cabrera, R.I. 2003. Demarcating salinity tolerance in greenhouse roses. Acta Hort. 609:51-57.

Cabrera, R.I. and P. Perdomo. 2003. Reassessing the salinity tolerance of greenhouse roses under soilless production conditions. HortScience 38:533-536.

Carter, M.R. 1980. Effects of sulphate and chloride soil salinity on growth and needle composition of siberian larch. Can. J. Plant Sci. 60:903-910.

de Vries, D.P. 2003. Rootstock, p. 2:633-638. In: A.V. Robert, T. Debener, and S. Gudin (eds.). Encyclopedia of rose science. Elsevier Academic Press, San Diego.

Fernández-Falcón, M., C.E. Álvarez, V. Garcia, and J. Baez. 1986. The effect of chloride and bicarbonate levels in irrigation water on nutrient content, production and quality of cut roses 'Mercedes'. Scientia Hort. 29:373-385.

Franklin, J.A., J.J. Zwiazek, S. Renault, and C. Croser. 2002. Growth and elemental composition of jack pine (Pinus banksiana) seedlings treated with sodium chloride and sodium sulfate. Trees (Berl.) 16:325-330.

Grattan, S.R. and C.M. Grieve. 1999. Salinity-mineral nutrient relations in horticultural crops. Scientia Hort. 78:127-157.

Hughes, H. and J. Hanan. 1978. Effect of salinity in water supplies on greenhouse rose production. J. Amer. Soc. Hort. Sci. 103:694-699.
Khan, A.H., M.Y. Ashraf, S.S.M. Naqvi, B. Khanzada, and M. Ali. 1995. Growth, ion and solute contents of sorghum grown under $\mathrm{NaCl}$ and $\mathrm{Na}_{2} \mathrm{SO}_{4}$ salinity stress. Acta Physiol. Plant. 17:261-268.

Manchanda, H.R. and S.K. Sharma. 1989. Tolerance of chloride and sulfate salinity in chickpea (Cicer arietinum). J. Agr. Sci. 113:407-410.

Martin, D. 2008. An overview of Rosa fortuniana rootstock. 30 Mar. $2008<$ http://www.pswdistrict.org/text/articles/rosaFortuniana Rootstock.html>.

Meiri, A., J. Kamburoff, and A. Poljakoff-Myber. 1971. Response of bean plants to sodium chloride and sodium sulphate salinization. Ann. Bot. (Lond.) 35:837-847.

Morrell, D.L. 1983. The roots of fortuniana ( $R . \times$ fortuniana). Amer. Rose Annu. 1983:55-72.

Navarro, J.M., C. Garrido, M. Carvajal, and V. Martinez. 2002. Yield and fruit quality of pepper plants under sulphate and chloride salinity. J. Hort. Sci. Biotechnol. 77:52-57.

Niu, G. and D.S. Rodriguez. 2006a. Relative salt tolerance of five herbaceous perennials. HortScience 41:1493-1497.

Niu, G. and D.S. Rodriguez. 2006b. Relative salt tolerance of selected herbaceous perennials and groundcovers. Scientia Hort. 110:352358.

Niu, G., D. Rodriguez, and L. Aguiniga. 2008. Response of growth and ion uptake of three rose rootstocks to saline water irrigation. HortScience 43:1479-1484.

Pemberton, H.B. 2003. Overview of roses and culture, p. 2:570-573. In: A.V. Robert, T. Debener, and S. Gudin (eds.). Encyclopedia of rose science. Elsevier Academic Press, San Diego.

Raviv, M., A. Krasnovsky, S. Medina, and R. Reuveni. 1998. Assessment of various control strategies for recirculation of greenhouse effluents under semi-arid conditions. J. Hort. Sci. Biotechnol. 73:485-491.

Rengasamy, P. 2006. World salinization with emphasis on Australia. J. Expt. Bot. 57:1017-1023.

Rogers, M.E., C.M. Grieve, and M.C. Shannon. 1998. The response of lucerne (Medicago sativa L.) to sodium sulphate and chloride salinity. Plant Soil 202:271-280.

Singh, B.P. and S.D. Chitkara. 1982. Effect of different salinity and sodicity levels on establishment and bud take performance of various rose rootstocks. Haryana J. Hort. Sci. 11:204-207.

Singh, B.P. and S.D. Chitkara. 1987. Effect of different salinity levels on water potential and proline content in leaves of various rose rootstocks. Indian J. Hort. 44:265-267.

Soltanpour, P.N., M.M. Al-Wardy, J.A. Ippolito, J.B. Rodriguez, J. Self, M. Gillaume, and D. Mathews. 1999. Chloride versus sulfate salinity effects on alfalfa shoot growth and ionic balance. Soil Sci. Soc. Amer. J. 63:111-116.

U.S. Environmental Protection Agency. 1983. Methods of chemical analysis of water and wastes (EPA-600/4-79-020). U.S. Govt. Printing Office, Washington, DC.

Wahome, P.K., H.H. Jesch, and I. Grittner. 2001. Mechanisms of salt stress tolerance in two rose rootstocks: Rosa chinensis 'Major' and R. rubiginosa. Scientia Hort. 87:207-216.

Wu, L., J. Chen, H. Lin, P. Van Mantgem, M. Ali Harivandi, and J.A. Harding. 1995. Effects of regenerant wastewater irrigation on growth and ion uptake of landscape plants. J. Environ. Hort. 13:92-96.

Wu, L., X. Gue, and A. Harivandi. 2001. Salt tolerance and salt accumulation of landscape plants irrigated by sprinkler and drip irrigation systems. J. Plant Nutr. 24:1473-1490. 